\title{
DAMPAK PERTUMBUHAN EKONOMI MITRA DAGANG TERHADAP NILAI EKSPOR INDONESIA
}

Studi Kasus: New Normal Era 2020 dan Normal Era 2019

\section{(The Effect of Economic Growth Trading Partner with Indonesia Export Value )}

\author{
Ghani Rahman Azis ${ }^{1}$, Ariful Romadhon ${ }^{2}$ \\ Badan Pusat Statistik ${ }^{1,2}$ \\ Banjarbaru, Indonesia \\ E-mail: ghani.azis@bps.go.id
}

\begin{abstract}
ABSTRAK
Pandemi Covid-19 telah menjadi kekhawatiran bagi negara-negara di seluruh dunia terutama dampak yang kemungkinan timbul ke pertumbuhan ekonomi negaranya. Banyaknya negara-negara yang telah resmi mengumumkan mengalami resesi atau kontraksi ekonomi telah menjadi kekhawatiran khususnya bagi pemerintah Indonesia. Hal ini karena Indonesia menerapkan perekonomian terbuka tidak terlepas dari keterikatan pada kegiatan ekspor-impor dengan negara-negara mitra dagang. Pertumbuhan ekonomi Indonesia sebesar $-5,32 \%$ pada kuartal kedua tahun 2020 menjadi peringatan dini bagi pemerintah dalam merumuskan kebijakan yang tepat agar Indonesia tidak ikut terjebak dalam jurang resesi ekonomi. Penelitian ini bertujuan untuk mengetahui gambaran pengaruh pertumbuhan ekonomi negara mitra dagang terhadap nilai ekspor Indonesia dengan periode waktu semester 1 tahun 2019 (normal era) dan 2020 (new normal era) sebagai variabel indikator menggunakan metode regresi linear berganda dengan efek interaksi. Hasil penelitian menunjukkan bahwa pertumbuhan ekonomi negara mitra dagang berpengaruh signifikan terhadap nilai ekspor Indonesia dan nilai ekspor Indonesia pada periode new normal era lebih tinggi secara persentase dibandingkan pada periode normal era. Adanya pengaruh pertumbuhan ekonomi negara mitra dagang terhadap nilai ekspor Indonesia menjadi tantangan tersendiri bagi pemerintah Indonesia untuk merumuskan kebijakan yang tepat agar Indonesia tidak ikut terjerumus ke jurang resesi ekonomi. Di sisi lain, nilai ekspor Indonesia pada new normal era yang lebih tinggi dibandingkan pada normal era menjadi peluang dan kesempatan yang bisa dimanfaatkan pemerintah untuk membantu menyelamatkan perekonomian Indonesia dari jurang resesi ekonomi.
\end{abstract}

Kata kunci: Ekspor, Pertumbuhan ekonomi, Regresi linear berganda, Variabel Indikator

\begin{abstract}
The Covid-19 pandemic has become a concern for countries around the world, especially the impact that may arise on their country's economic growth. The number of countries that have officially announced that they are experiencing a recession or economic contraction has become a particular concern for the Indonesian government. This is because Indonesia implements an open economy that is inseparable from its attachment to export-import activities with trading partner countries. Indonesia's economic growth of $5.32 \%$ in the second quarter of 2020 is an early warning for the government in formulating the right policies so that Indonesia does not get caught in the brink of economic recession. This study aims to describe the effect of economic growth in trading partner countries on the value of Indonesia's exports with the period of semester 1 of 2019 (normal era) and 2020 (new normal era) as indicator variables using multiple linear regression method with interaction effects. The results showed that the economic growth of trading partner countries had a significant effect on the value of Indonesia's exports and that the value of Indonesian exports in the new normal era was higher in percentage than in the normal period of the era. The influence of the economic growth of trading partner countries on the value of Indonesian exports is a challenge for the Indonesian government to formulate the right policies so that Indonesia does not fall into the brink of economic recession. On the other hand, the value of Indonesia's exports in the new normal era which was higher than in the normal era was an opportunity and opportunity that the government could use to help save the Indonesian economy from the brink of economic recession.
\end{abstract}

Keywords: Export, Economic Growth, Multiple Linear Regression, Indicator Variable 


\section{PENDAHULUAN}

Pandemi Covid-19 (Coronavirus Disease 2019) telah menjadi kekhawatiran bagi negaranegara di seluruh dunia terutama dampak yang timbul ke pertumbuhan ekonomi negaranya. Tidak hanya bagi negara miskin atau negara berkembang, namun juga bagi negara maju yang khawatir akan masuk ke dalam jurang resesi ekonomi. Suatu negara dikatakan mengalami resesi ekonomi apabila terjadi penurunan pada nilai Real Gross Domestic Product (GDP) setidaknya pada dua kuartal berturut-turut (Mankiw, 2012). Menurut data dari Trading Economics, sampai dengan kuartal dua tahun 2020 (bulan September) tercatat setidaknya 44 negara yang sudah mengumumkan kondisi negaranya yang mengalami resesi ekonomi yang utamanya akibat adanya dampak pandemi Covid-19 bagi negaranya. Namun, tidak sedikit juga negara-negara yang sudah mengumumkan telah mengalami kontraksi pertumbuhan ekonomi yang cukup dalam terutama di kuartal dua tahun 2020. Masuknya suatu negara ke dalam jurang resesi membuat negara-negara di sekitarnya juga akan terancam masuk ke dalam jurang yang sama. Karena satu negara dengan negara lain terikat pada bidang perdagangan internasional (CNBC Indonesia, 2020). Penurunan ekonomi karena pandemi Covid-19 adalah yang terburuk sejak depresi besar (resesi berkepanjangan) pada 1930-an. Wabah berkepanjangan akan menguji kemampuan negara-negara di dunia dan bank sentral dalam mengendalikan krisis (International Monetary Fund, 2020).

Indonesia sebagai negara yang menerapkan perekonomian terbuka tidak terlepas dari ancaman resesi akibat kontraksi pertumbuhan ekonomi negara lain. Hal ini disebabkan oleh adanya keterikatan pada kegiatan ekspor-impor Indonesia dan negara-negara mitra dagang. Pada tahun 2019, kontribusi ekspor barang dan jasa dalam perekonomian Indonesia mencapai 18,41 persen dengan nilai mencapai 2.914.635,60 miliar rupiah (Badan Pusat Statistik, 2019). Pertumbuhan ekonomi suatu negara akan memengaruhi ekspor dalam negeri. Selain itu, terdapat ada hubungan kausalitas dua arah antara pertumbuhan ekonomi dan ekspor dalam jangka panjang (Aydin \& Sari, 2014). Selain itu, terdapat hubungan yang searah antara ekspor dan pertumbuhan ekonomi baik secara langsung maupun tidak langsung (Iqbal, dkk, 2012). Dengan demikian, pertumbuhan ekspor suatu negara akan menentukan besarnya pertumbuhan ekonomi negara tersebut.

Sejak pandemi Covid-19 melanda khususnya di Indonesia, pada kuartal kedua pertumbuhan ekonomi Indonesia mengalami kontraksi yang semakin dalam dibanding kuartal pertama, yaitu anjlok menjadi minus 5,32\% (Yoy) atau mengalami kontraksi 4,19\% dibandingkan kuartal pertama (Badan Pusat Statistik, 2020). Di sisi lain, sampai kuartal kedua 2020, beberapa mitra dagang Indonesia sudah mengumumkan negaranya mengalami resesi (Yoy) seperti Amerika Serikat, Singapura, Thailand, Jerman, Jepang, dan Inggris. Namun, Tiongkok sebagai negara mitra dagang terbesar Indonesia mengalami pertumbuhan ekonomi positif sebesar 3,2\% dibandingkan dengan periode yang sama tahun sebelumnya (Yoy). Adanya beberapa negara mitra dagang yang sudah mengumumkan resesi menjadi lampu kuning bagi Indonesia untuk lebih waspada dan antisipatif dalam menghadapi munculnya resesi ekonomi. Namun, patutkah Indonesia khawatir akan mengalami resesi ekonomi karena adanya kontraksi pertumbuhan ekonomi negara lain? Kemudian, seberapa besar dampak pertumbuhan ekonomi negara lain dalam memengaruhi nilai ekspor Indonesia?

Tujuan penelitian ini adalah memberikan gambaran mengenai faktor apa saja yang berpengaruh dalam nilai ekspor Indonesia dan seberapa besar perbedaan nilai ekspor Indonesia dalam kurun waktu perbandingan sebelum pandemi Covid-19 (normal era) tahun 2019 dan selama pandemi Covid-19 (new normal era) tahun 2020.

\section{METODE}

Penelitian ini menggunakan metode analisis deskriptif dan inferensia. Analisis deskriptif sebagai alat untuk melihat gambaran umum nilai ekspor Indonesia dan pertumbuhan ekonomi negara mitra dagang. Sementara analisis inferensia yaitu menggunakan regresi linear berganda dengan variabel indikator digunakan untuk menjelaskan pengaruh variabel independen terhadap 
variabel dependen dalam penelitian. Dalam model regresi linear berganda ini dilakukan dengan cara mencari model terbaik yaitu dengan pengujian model secara simultan menggunakan Uji-F dan pengujian model secara parsial menggunakan Uji-t. Selanjutnya dari model yang terbentuk dihitung nilai residual untuk melakukan pengujian dan pengecekan asumsi klasik berupa asumsi Normalitas, Homokedasitas, dan Non Multikolinearitas.

Objek penelitian ini adalah 29 negara mitra dagang (ekspor) terbesar Indonesia. Pendekatan dalam penelitian ini adalah pendekatan kualitatif dan kuantitatif dengan data yang bersumber dari Badan Pusat Statistik, Trading Economics dan International Monetary Fund. Data dalam penelitian ini menggunakan dua titik waktu, yaitu pada semester 1 (kuartal 1 dan 2) tahun 2019, dalam hal ini mewakili kondisi sebelum pandemi Covid-19 (normal era), dan semester 1 (kuartal 1 dan 2) tahun 2020, dalam hal ini mewakili kondisi selama pandemi Covid-19 (new normal era). Variabel respons (dependen) yang digunakan berupa nilai ekspor Indonesia ke negara mitra dagang dalam bentuk logartima natural (Ln). Variabel bebas (independen) dalam penelitian ini berupa nilai pertumbuhan ekonomi dan nilai kurs negara mitra dagang dan dummy variable.

Penelitian ini menggunakan metode analisis mengikuti model regresi linear berganda dengan variabel indikator (Neter et al., 1983). Dalam hal ini persamaan model yang digunakan dalam penelitian ini yaitu:

$$
\operatorname{Ln} Y_{i}=\beta_{0}+\beta_{1} X_{i 1}+\beta_{2} X_{i 2}+\beta_{3} X_{i 3}+\varepsilon_{i}
$$

dimana:

$\operatorname{Ln} Y_{i} \quad=$ Nilai ekspor ke negara mitra dagang Indonesia ke-i (\%)

$\beta_{i} \quad=$ Nilai Konstanta ke-i

$X_{i 1} \quad=$ Pertumbuhan ekonomi dari negara mitra dagang Indonesia ke-i (\%)

$X_{i 2}=$ Nilai kurs terhadap US\$ negara mitra dagang Indonesia ke-i

$X_{i 3}=$ Variabel Indikator dengan 1, jika new normal era (pandemi covid-19), dan

0 , jika normal era (sebelum pandemi covid-19)

Persamaan fungsi dari model tersebut yaitu:

$$
E(Y)=\beta_{0}+\beta_{1} X_{1}+\beta_{2} X_{2}+\beta_{3} X_{3}
$$

Apabila variabel $X_{3}$ bernilai 0 maka persamaan model menjadi: $E(Y)=\beta_{0}+\beta_{1} X_{1}+\beta_{2} X_{2}$ ， dalam hal ini mencerminkan kondisi Normal Era. Kemudian, apabila variabel $X_{3}$ bernilai 1 , maka persamaan model menjadi: $E(Y)=\left(\beta_{0}+\beta_{3}\right)+\beta_{1} X_{1}+\beta_{2} X_{2}$ dalam hal ini mencerminkan kondisi New Normal Era.

Dalam penggunaan data kualitatif, faktor efek interaksi dalam model dapat terjadi. Faktor efek interaksi ini merupakan hasil perkalian antara variabel indikator dan variabel bebas dalam model. Model persamaan dengan efek interaksi yaitu:

$$
\operatorname{Ln} Y_{i}=\beta_{0}+\beta_{1} X_{i 1}+\beta_{2} X_{i 2}+\beta_{3} X_{i 3}+\beta_{4} X_{i 1} X_{i 3}+\varepsilon_{i}
$$

dimana:

$X_{i 1} X_{i 3}=$ variabel faktor efek interaksi antara Variabel Pertumbuhan Ekonomi dan variabel indikator

Sehingga, persamaan fungsi yang terbentuk yaitu:

$$
E(Y)=\beta_{0}+\beta_{1} X_{1}+\beta_{2} X_{2}+\beta_{3} X_{3}+\beta_{4} X_{1} X_{3}
$$




\section{HASIL DAN PEMBAHASAN}

\section{Gambaran Nilai Ekspor Indonesia ke Mitra Dagang Utama Semester 12019 dan 2020}

Indonesia menerapkan perekonomian terbuka sehingga tidak terlepas dari adanya kegiatan ekspor maupun impor dengan negara lain. Dalam hal kegiatan ekspor, pada semester 1 tahun 2019 total nilai ekspor Indonesia ke 29 negara mitra dagang utama Indonesia mencapai 72.076 juta US\$. Sedangkan pada semester 1 tahun 2020 mencapai 67.327 juta US\$. Negara Tiongkok menjadi negara tujuan ekspor terbesar dengan kontribusi ekspor mencapai 17,01 persen dan 20,44 masing-masing pada semester 1 tahun 2019 dan tahun 2020 dari total nilai ekspor ke 29 negara mitra dagang utama. Disusul negara Amerika Serikat (11,78\% dan $12,75 \%)$, Jepang (11,17\% dan $10 \%)$, Singapura (8,55\% dan 8,39\%), dan India (8,04\% dan 7,05\%).

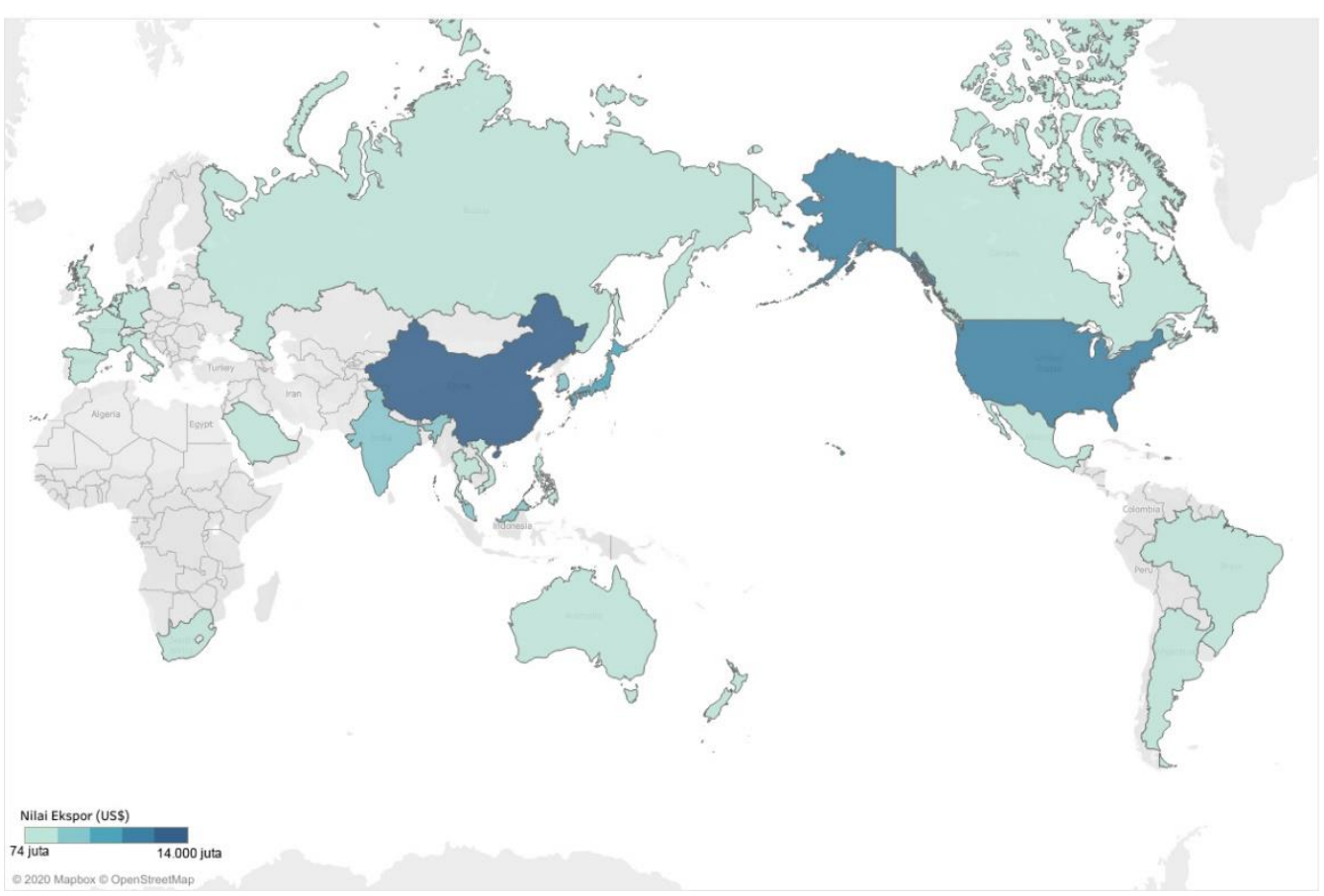

Gambar 1. Nilai Ekspor Indonesia ke 29 Negara Mitra Dagang periode Semester 1 Tahun 2019

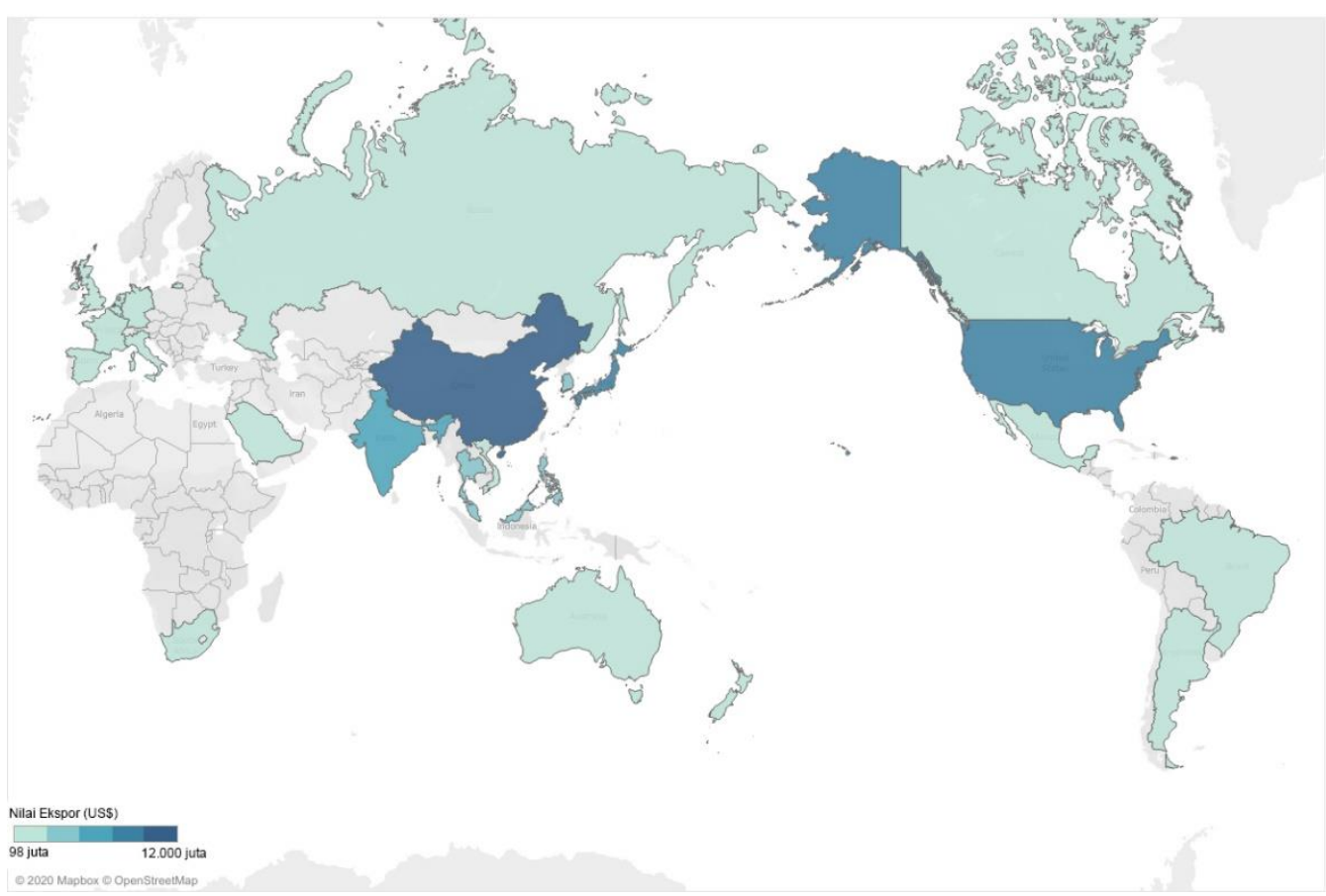

Gambar 2. Nilai Ekspor Indonesia ke 29 Negara Mitra Dagang periode Semester 1 Tahun 2020 
Pada Gambar 1 dan Gambar 2, dapat dilihat perbandingan nilai ekspor Indonesia ke 29 negara mitra dagang utama (dalam US\$) pada periode semester 1 tahun 2019 dan 2020. Dari ke 29 negara mitra dagang utama Indonesia, pada periode semester 1 tahun 2020 (Yoy) terdapat 6 negara mitra dagang dengan pertumbuhan nilai ekspor Indonesia yang positif sedangkan 23 negara lainnya mengalami pertumbuhan nilai ekspor Indonesia yang negatif. Negara mitra dagang dengan pertumbuhan nilai ekspor Indonesia yang positif diantaranya negara Tiongkok, Amerika Serikat, Australia, Italia, Belgia, dan Rusia dengan pertumbuhan nilai ekspor tertinggi yaitu negara Tiongkok dengan kenaikan mencapai 12 persen dibandingkan periode semester 1 tahun 2019. Peningkatan nilai ekspor yang positif menjadi angin segar bagi Indonesia di tengah ancaman resesi ekonomi yang semakin menghantui perekonomian negara Indonesia. Sebagaimana diketahui, nilai ekspor menjadi salah satu variabel penyusun dalam penghitungan GDP suatu negara.

\section{Gambaran Pertumbuhan Ekonomi Mitra Dagang Utama Semester 12019 dan 2020}

Pertumbuhan ekonomi suatu negara dihitung dari pertumbuhan nilai Gross Domestic Product (GDP) negara yang bersangkutan. Dari 29 negara mitra dagang utama Indonesia, negara dengan pertumbuhan ekonomi tertinggi pada periode semester 1 tahun 2019 yaitu negara Vietnam $(6,76 \%)$, disusul Tiongkok (6,27\%), Filipina (5,55\%), India (5,45\%), dan Malaysia (4,65\%). Sedangkan negara dengan pertumbuhan ekonomi terendah pada periode yang sama yaitu Argentina $(-2,88 \%)$, Turki $(-2,13 \%)$, dan Meksiko (-0,02\%).
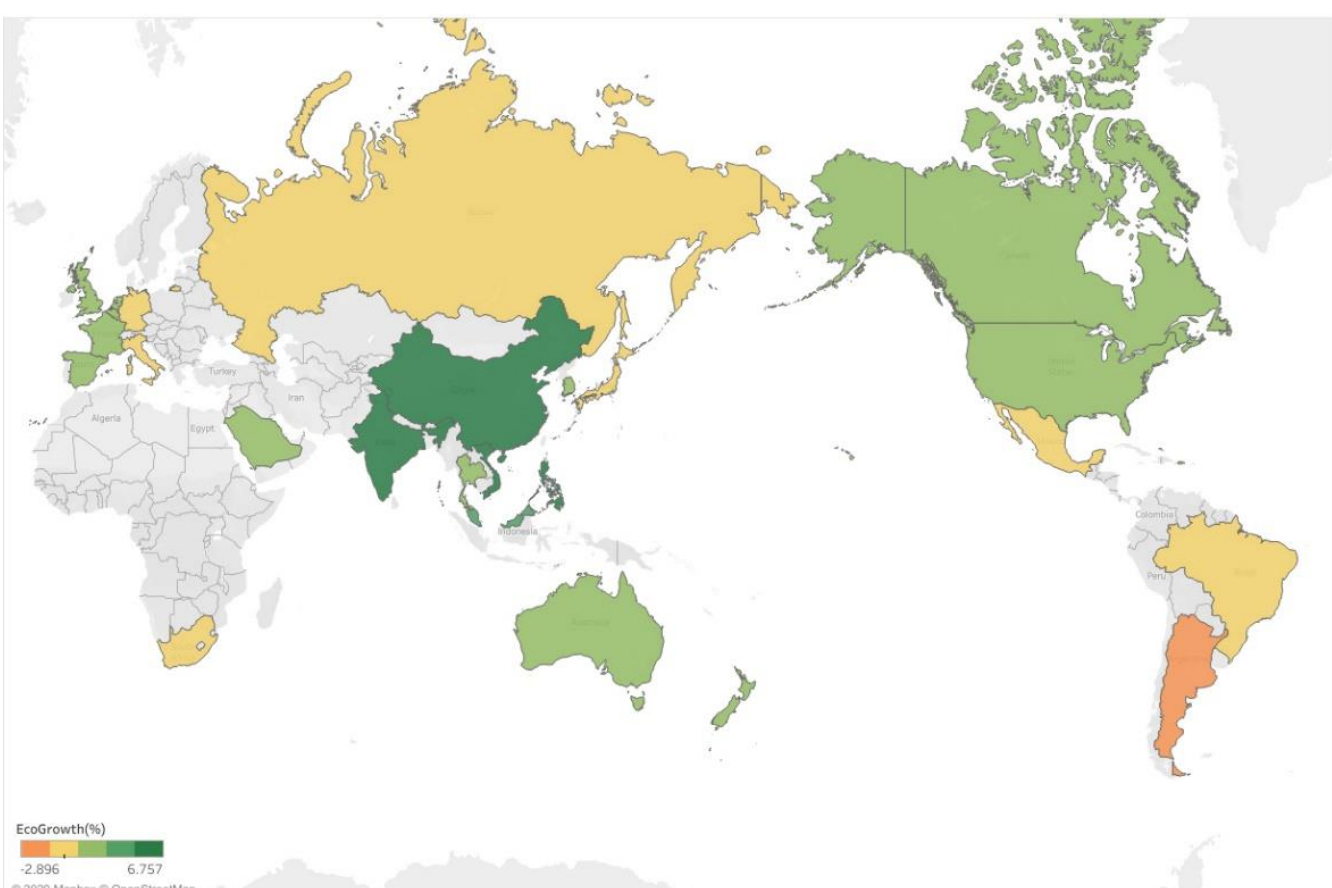

Gambar 3. Pertumbuhan Ekonomi 29 Negara Mitra Dagang Indonesia periode Semester 1 Tahun 2019 


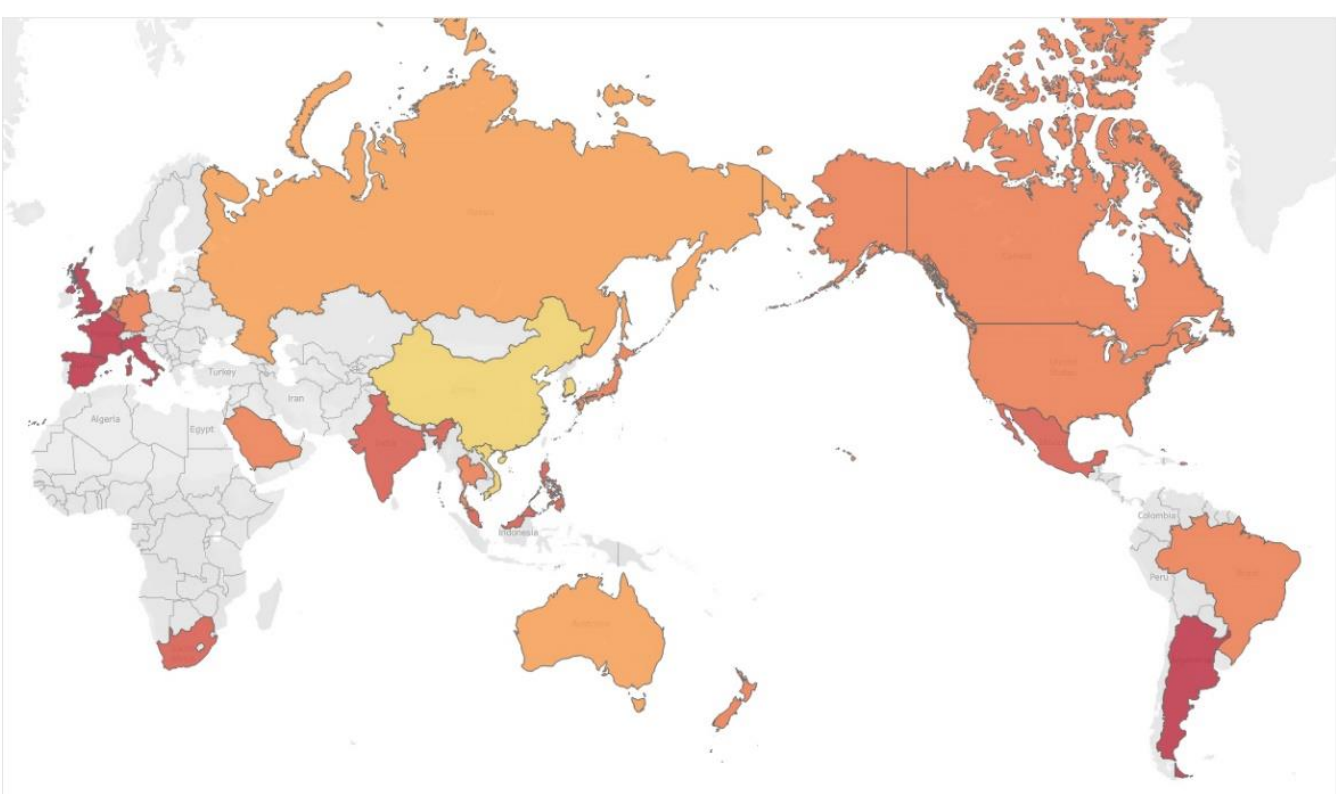

Gambar 4. Pertumbuhan Ekonomi 29 Negara Mitra Dagang Indonesia periode Semester 1 Tahun 2020

Untuk melihat perbandingan kondisi perekonomian dari 29 negara mitra dagang utama Indonesia bisa dilihat pada Gambar 3 dan Gambar 4. Jika pada periode semester 1 tahun 2019 masih banyak negara yang dapat mencapai pertumbuhan ekonomi yang positif, maka lain halnya dengan kondisi perekonomian pada periode semester 1 tahun 2020. Dari 29 negara mitra dagang utama Indonesia, hanya terdapat dua negara saja yang masih menunjukkan kinerja perekonomian yang positif, yaitu Vietnam dan Taiwan walaupun dengan nilai pertumbuhan yang tidak terlalu besar. Sedangkan 27 negara lainnya menunjukkan perlambatan ekonomi pada semester 1 tahun 2020 (Yoy) yaitu negara Spanyol yang mengalami pertumbuhan ekonomi terendah sebesar minus 13,13 persen disusul negara Argentina (-12,52\%), Perancis $(-12,31 \%)$, Inggris $(-11,7 \%)$, dan Italia $(-11,6 \%)$. Pertumbuhan ekonomi yang rendah ini lebih disebabkan karena adanya pandemi Covid-19 yang telah memengaruhi aktivitas perekonomian di seluruh negara. Rendahnya pertumbuhan ekonomi negara-negara tersebut patut diwaspadai Indonesia mengingat negaranegara tersebut merupakan mitra dagang utama Indonesia dalam aktivitas ekspor Indonesia.

\section{Dampak Pertumbuhan Ekonomi Mitra Dagang Terhadap Nilai Ekspor Indonesia Semester 12019 dan 2020}

Untuk melihat dampak atau pengaruh dari tingkat pertumbuhan ekonomi mitra dagang terhadap nilai ekspor Indonesia secara kuantitatif dapat dilihat melalui analisis inferensia. Dalam penelitian ini, analisis inferensia dilakukan dengan menggunakan metode estimasi Regresi Linier Berganda (RLB). Berhubung dalam penelitian ini menggunakan variabel indikator, maka perlu untuk mengestimasi signifikansi dari faktor interaksi terlebih dahulu. Melalui uji-t yang dilakukan diperoleh hasil nilai uji sebesar -0,546 ( $p$-value $>0,05)$ sehingga dapat disimpulkan bahwa variabel efek interaksi tidak signifikan. Oleh karena itu, dalam penelitian ini menggunakan metode estimasi Regresi Linear Berganda (RLB) tanpa efek interaksi. Hasil perhitungan diperoleh model sebagai berikut:

$$
\operatorname{Ln} \widehat{\text { Ekspor }}_{l}=20,65+0,18 \text { Growth }_{i}^{*}-2,35 \times 10^{-5} \operatorname{Kurs}_{i}^{*}+1,45 \text { Dummy }_{i}^{*}
$$

Berdasarkan model di atas dilakukan pengujian signifikansi variabel dengan menggunakan uji $\mathrm{F}$ (simultan) dan uji t (parsial). Dalam pengujian ini diperoleh kesimpulan bahwa model yang terbentuk merupakan model terbaik (fit) dengan nilai uji $F$ sebesaar $4,895(p<0,05)$ dengan nilai koefisien determinansi sebesar 21,4 persen. Artinya, model yang diperoleh dapat menjelaskan keragaman variabel nilai ekspor sebesar 21,4 persen dari variabel Pertumbuhan Ekonomi dan Kurs 
sedangkan sisanya dijelaskan oleh variabel lain yang tidak dimasukkan ke dalam model. Kemudian, melalui uji-t (parsial) dapat diperoleh kesimpulan bahwa variabel-variabel yang memengaruhi secara siginifikan Nilai ekspor Indonesia ke negara mitra dagang yaitu Pertumbuhan Ekonomi dan variabel indikator, sedangkan variabel nilai Kurs tidak berpengaruh signifikan dalam model yang terbentuk.

Dalam penggunaan model regresi linier, perlu dilakukan pengujian asumsi klasik untuk melihat kelayakan model yang terbentuk. Dari pengujian asumsi klasik yang telah dilakukan, yaitu uji normalitas, multikolinearitas, dan homoskedastisitas, diperoleh hasil bahwa model yang terbentuk sudah memenuhi asumsi-asumsi dalam Ordinary Least Square (OLS) sehingga model yang terbentuk sudah layak.

Dari model yang terbentuk dapat dijelaskan bahwa nilai ekspor Indonesia ke 29 negara mitra dagang utama dipengaruhi oleh Pertumbuhan Ekonomi negara mitra dagang dengan koefisien regresi sebesar 0,18. Artinya, untuk setiap peningkatan pertumbuhan ekonomi negara mitra dagang sebesar 1 persen maka akan meningkatkan nilai ekspor Indonesia sebesar 0,18 persen apabila faktor-faktor lain yang memengaruhi nilai ekspor dianggap konstan. Hal ini sejalan dengan penelitian terkait bahwa pertumbuhan ekonomi suatu negara akan memengaruhi ekspor dalam negeri (Aydin \& Sari, 2014). Sementara itu, variabel nilai kurs tidak signifikan memengaruhi ekspor dalam negeri. Hal itu dikarenakan, terdapat faktor-faktor lain seperti permintaan dan penawaran pasar lebih mempengaruhi pertumbuhan ekspor dibandingkan dengan kurs (Marinković \& dkk, 2018). Kemudian, dalam model yang terbentuk dapat disimpulkan bahwa dalam new normal era (semester 1 tahun 2020) terjadi peningkatan nilai ekspor dibandingkan dengan normal era (semester 1 tahun 2019). Selama new normal era, nilai ekspor Indonesia lebih tinggi sebesar 1,45 persen jika dibandingkan dengan kondisi sebelum pandemi Covid-19 (normal era). Mengacu pada data BPS, komoditas ekspor non migas yang memiliki pertumbuhan positif selama periode JanuariJuni 2020 dibandingkan dengan periode yang sama tahun sebelumnya diantaranya golongan barang (HS) lemak dan minyak hewan/nabati (15), besi dan baja (72), dan pupuk (31). Sedangkan ekspor migas yang memiliki pertumbuhan positif, yaitu berupa komoditas industri pengolahan hasil minyak.

Adanya pengaruh pertumbuhan ekonomi negara mitra dagang Indonesia terhadap pertumbuhan ekspor dalam negeri menjadi tantangan tersendiri bagi pemerintah Indonesia. Banyaknya negara yang sudah mengalami kontraksi pertumbuhan ekonomi bahkan sudah masuk ke dalam jurang resesi bisa menjadi lampu kuning bagi pemerintah dalam menentukan kebijakan yang tepat utamanya dalam menjaga neraca perdagangan agar tetap surplus. Namun, disisi lain dalam new normal era semester 1 tahun 2020, pertumbuhan ekspor Indonesia menunjukkan kinerja yang cukup menggembirakan dibandingkan pada normal era semester 1 tahun 2019. Hal ini menjadi peluang bagi pemerintah untuk terus menggenjot produk eskpor dalam negeri yang sedang mengalami peningkatan permintaan di pasar internasional.

\section{KESIMPULAN}

Indonesia yang menerapkan perekonomian terbuka tidak terlepas dari adanya aktivitas ekspor dan impor di perdagangan internasional. Nilai ekspor yang menjadi salah satu penyusun nilai GDP menjadi tantangan tersendiri bagi pemerintah untuk bisa menentukan kebijakan yang tepat agar nilai ekspor bisa memberikan kontribusi yang positif (surplus) bagi perekonomian dalam negeri. Pertumbuhan ekspor Indonesia yang dipengaruhi pertumbuhan ekonomi negara mitra dagang bisa menjadi early warning mengingat sudah banyak negara yang mengalami kontraksi pertumbuhan ekonomi bahkan sudah masuk ke dalam jurang resesi. Setiap kenaikan 1 persen pertumbuhan ekonomi negara mitra dagang akan berdampak pada kenaikan nilai ekspor Indonesia sebesar 0,18 persen dengan tingkat signifikansi 0,05 persen. Disisi lain, pertumbuhan ekspor Indonesia selama semester 1 tahun 2020 (new normal era) lebih tinggi sebesar 1,45 persen dibandingkan semester 1 tahun 2019 (normal era). Komoditas ekspor yang mengalami pertumbuhan nilai ekspor yang positif bisa menjadi peluang bagi Indonesia dalam membantu meningkatkan nilai perekonomian 
nasional. Bukan tidak mungkin pertumbuhan ekspor Indonesia yang positif bisa menyelamatkan Indonesia dari dalam jurang resesi ekonomi selama pandemi Covid-19 berlangsung.

\section{DAFTAR PUSTAKA}

Aydin, M., \& Sari, M. (2014). Relationship Between GDP and Export In Turkey. Annals of the University of Craiova, Physics.

Badan Pusat Statistik. (2019). Distribusi PDB Seri 2010 Triwulanan Atas Dasar Harga Berlaku menurut Pengeluaran (Persen). https://www.bps.go.id/indicator/169/110/2/-seri-2010-distribusi-pdb-seri-2010triwulanan-atas-dasar-harga-berlaku-menurut-pengeluaran.html.

Badan Pusat Statistik. (2020). Perkembangan Ekspor dan Impor Indonesia juni 2020. Badan Pusat Statistik. https://www.bps.go.id/pressrelease/2020/07/15/1680/ekspor-juni-2020-mencapai-us-12-03-miliar-danimpor-juni-2020-sebesar-us-10-76-miliar.html

CNBC Indonesia. (2020). 44 Negara Resmi Resesi, Ekonomi Eropa Terparah.

https://finance.detik.com/berita-ekonomi-bisnis/d-5138964/14-negara-resmi-resesi-13-negara-lagidipastikan-nyusul

International Monetary Fund. (2020). Virus corona: Karena wabah, dunia hadapi resesi yang lebih buruk daripada Depresi Besar tahun 1930-an - BBC News Indonesia. https://www.bbc.com/indonesia/dunia52295243

Iqbal, A., \& dkk. (2012). Relationship between exports and economic growth of Pakistan. European Journal of Social Sciences, 32(3), 453-460.

Mankiw, N. G. (2012). Principles of macroeconomics 6th edition. Thompson South-Western Cengage.

Marinković, \& dkk. (2018). Exchange rate and export performance: Evidence from Serbia. Contributions to Economics, 51-67. https://doi.org/10.1007/978-3-319-93452-5_4

Neter, J., William, W., \& Kutner, M. H. (1983). Applied Linear Regression Models.

Trading Economy. (2020). https://www.tradingeconomy.com. 